九州大学学術情報リポジトリ

Kyushu University Institutional Repository

\title{
The Role of Captivation and Sensation in Pleasurable Experience to Enhance Wayfinding Process
}

Narindrasani, Sekar

Graduate of Department of Architecture, Universitas Indonesia

Fuad, Hery, Achmad

Lecturer of Department of Architecture, Universitas Indonesia

https://doi.org/10.5109/2740948

出版情報: Evergreen. 7 (1)，pp.67-71，2020-03. 九州大学グリーンテクノロジー研究教育センター バージョン：

権利関係 : 


\title{
The Role of Captivation and Sensation in Pleasurable Experience to Enhance Wayfinding Process
}

\author{
Sekar Narindrasani ${ }^{1}$, Achmad Hery Fuad ${ }^{2 *}$ \\ ${ }^{1}$ Graduate of Department of Architecture, Universitas Indonesia, Depok, Indonesia \\ ${ }^{2}$ Lecturer of Department of Architecture, Universitas Indonesia, Depok, Indonesia \\ *Author to whom correspondence should be addressed: \\ E-mail: heryfuad@gmail.com
}

(Received November 1, 2019; Revised January 23, 2020; accepted February 24, 2020).

\begin{abstract}
Many factors have influenced the livability of a city; one of them is a pleasant environment. By examining the activities and the points of reference in public spaces as well as their influence on the visitors' behaviors, this paper aims to explore pleasurable experience in public spaces as a potential way to create easy and exciting wayfinding schemes for the visitors. The methods employed for analysis are based on the theories of Passini, Costello and Edmond, and Berlyne. The data are collected through active observation, mapping, and picture taking at the Jakarta Old Town (also known as Kota Tua Jakarta) on the weekends, when public activity is the most frequent. This paper reveals that the pleasurable experience that helps the visitors' wayfinding is mostly derived from the visual aspects involving human activities. These visual aspects provide positive feedback to the visitors, such as the constructed meaning to a related place by stimulating captivation and sensation of the involved subjects.
\end{abstract}

Keywords: wayfinding; pleasurable; reference point; experience; livable

\section{Introduction}

The livability of a city that is part of the sustainable development, also affects the liveliness of its streets ${ }^{1)}$, and it is influenced by many factors such as the presence of people, the provision of activities ${ }^{2}$, comfort $^{1)}$, the presence of a symbol of an environmentally friendly society ${ }^{3)}$, human thermal comfort $^{4}$, and a pleasing environment ${ }^{5}$. Several prior studies have examined wayfinding in detail, and they mainly inquire into the ways to improve the ability of wayfinding through various methods: color $^{()}$, lighting ${ }^{7}$, sound $^{8)}$, interior $\left.{ }^{9}, 10\right)$, smell $^{11)}$, travel mode ${ }^{12)}$, equipment ${ }^{13)}$, building layout ${ }^{14)}$, and providing auditory information ${ }^{15}$. As for the subject of pleasurable experience, there have been only discussions about its applicability in interactive design ${ }^{16)}$, and retail ${ }^{17)}$, its changes in urban environment ${ }^{18}$, and its correlation with sociocultural aspects ${ }^{19}$ ). In other words, none of these discussions have tried to explore how pleasurable experience has possibilities in accommodating wayfinding in public spaces. Examining the activities and the points of reference in public spaces along with their influence on the behavior of the visitors, this paper observes the meanings that these activities and reference points may have. The goal of this paper is to investigate the feasible opportunities of pleasurable experience in public spaces to create easy and exciting wayfinding schemes at tourist attractions by enhancing their liveliness.

\section{Literature Review}

\subsection{Wayfinding}

Wayfinding is a human cognitive process ${ }^{20)}$ or a spatial problem-solving method that consists of absorbing information from the surrounding environment, making a decision plan, and executing the plan in the form of spatial behavior $^{21,22)}$. In addition, Kevin Lynch explains that wayfinding is an action of utilizing and organizing sensory cues from the environment ${ }^{21}$. In wayfinding, a person utilizes mental representations of the area, commonly known as cognitive maps ${ }^{21}$. The cognitive mapping process itself is an accumulation of psychological transformation processes, in which one uses the environmental knowledge that they obtain from the everyday spatial life in their environment.

There are two sources of the environmental information needed to construct cognitive maps. The first is memory information, otherwise known as the information associated with human memory, and the second is sensory information, which is acquired directly from the environment. The information from these two sources creates an "image" (imageability), and it is later combined into a "structure" that makes it into cognitive maps ${ }^{21)}$. Although physical elements are predominant, meaning is another essential contributor to the formation of cognitive 
maps $^{23,24)}$. Meaning can be categorized into three types: functional nature or the meaning given from an object's functions, socio-symbolic nature or the meaning given by the community, and the meaning derived from sensory experience $^{21)}$.

The next steps of the wayfinding cognitive process are decision making and decision execution respectively, and these steps are constantly evolving. With that said, the term "decision points" is introduced, and it is where all decisions are considered, evaluated, and narrowed down into the final plan for the execution.

Wayfinding is not always related to only efficiency. Passini $^{21)}$ mentions that there are two different systems of wayfinding: the functional nature of wayfinding which prioritizes efficiency and the evaluative nature of wayfinding with a great emphasis on experience. Passini $^{21)}$ also notes the value of wayfinding as a pleasurable problem-solving activity, in which a person's wayfinding is motivated by the pleasure derived from encountering new things; he later calls this "recreational wayfinding" (evaluative nature).

\subsection{Pleasure}

Mehrabian and Russell's framework of sensationconsisting of pleasure, arousal, and dominance-outlines the stimulants that influence our actions ${ }^{25}$. Pleasure itself can also be associated with curiosity, well-being, and comfort. Furthermore, Costello and Edmonds ${ }^{16)}$ have developed the pleasure framework, which is a summary of the theories of six authors.

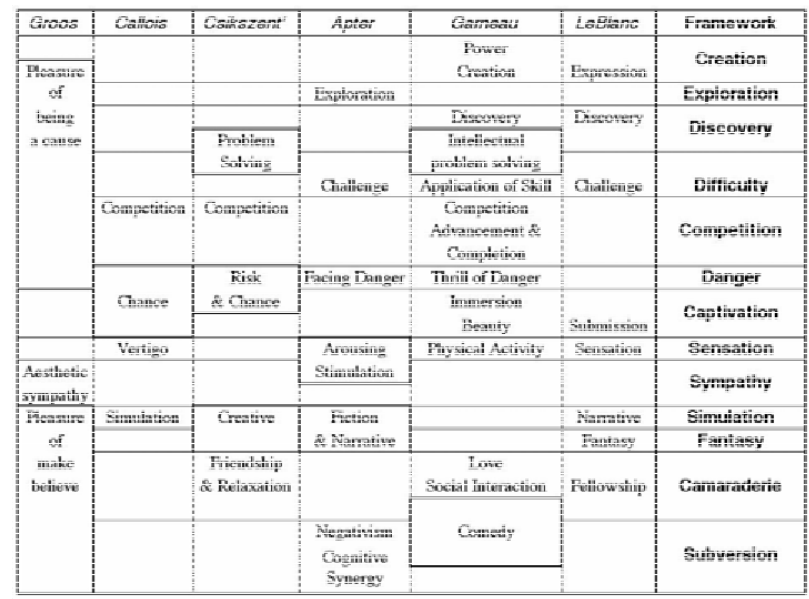

Fig. 1: The pleasure framework by Costello and Edmonds ${ }^{16)}$

The thirteen aspects of the above framework are considered to be the common generators of pleasurable sensations. However, this paper focuses on only two out of the thirteen aspects; the first is captivation, a pleasurable feeling gained when a person is attracted to or interested in something, whereas the second is sensation, a pleasurable feeling gained from doing something. In addition, there is an opinion on how urban settings that have stimulating areas can affect the perception and movement of the subjects within them. For example, the stimuli from an environment's sensory experience are able to deepen the subjects' bond with the area and improve their orientation ${ }^{26)}$. Berlyne's ${ }^{27}$ ) theory of aesthetic response posits that an environment can create hedonic value, where a stimulant triggers arousal to the related subjects. The hedonic value comes from the responses created by the subjects when encountering a certain stimulant in the environment, such as a sense of pleasure generated by captivation and sensation.

\section{Methods}

The methods used in this research are based on the theories of Passini ${ }^{21)}$, Costello and Edmonds ${ }^{16)}$, and Berlyne $^{27)}$, and their implementations are done through active observation, mapping, and picture taking. The observation takes place in the Jakarta Old Town, also known as Kota Tua Jakarta. The observation is conducted on the weekends, when public activities and events occur most frequently-thus making the place's atmosphere more energetic and lively. The observation period lasts for three weeks (six times), and the observation components are the activities and the possible points of reference for wayfinding in every available decision point. There are seven decision points in total, and each decision point is different in their characteristics.

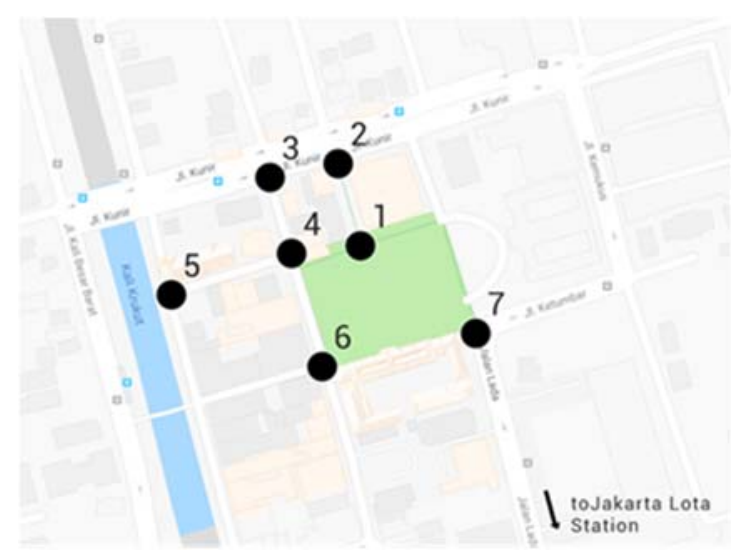

Fig. 2: The location of the observed decision points across the Jakarta Old Town

\section{Results and Discussion}

Table 1. The observation result of the decision points, the number of reference points in each decision point corresponding with its area density.

\begin{tabular}{|c|c|c|c|c|c|}
\hline \multirow{2}{*}{$\begin{array}{c}\text { Decisi } \\
\text { on } \\
\text { Point }\end{array}$} & $\begin{array}{c}\text { Intersect } \\
\text { ion }\end{array}$ & $\begin{array}{c}\text { Area } \\
\text { Densi } \\
\text { ty }\end{array}$ & $\begin{array}{c}\text { Total } \\
\text { (Physic } \\
\text { al } \\
\text { Objects } \\
+\end{array}$ & $\begin{array}{c}\text { Physi } \\
\text { cal } \\
\text { Objec } \\
\text { ts }\end{array}$ & $\begin{array}{c}\text { Activit } \\
\text { ies }\end{array}$ \\
\hline 1 & 3 & High & 4 & 0 & 4 \\
\hline
\end{tabular}




\begin{tabular}{|l|l|l|l|l|l|}
\hline 2 & 3 & High & 3 & 0 & 3 \\
\hline 3 & 3 & Low & 2 & 1 & 1 \\
\hline 4 & 4 & Low & 3 & 2 & 1 \\
\hline 5 & 3 & Low & 2 & 2 & 0 \\
\hline 6 & 3 & High & 5 & 3 & 2 \\
\hline 7 & 4 & High & 3 & 1 & 2 \\
\hline
\end{tabular}

Figure 3).

This statement is further supported by the fact that the signature attractions of the Old Town - namely its historic buildings and their façade - are now mostly blocked by construction fences, air conditioning machines, photo booths, and street vendors; it may appear that the Old Town buildings are becoming unpopular. However, there are also areas where the buildings and their façade are unobstructed, yet they remain quiet and devoid of visitors (see Figure 4). The empty unobstructed areas reveal that the visitors' interest is not in the elements of the Old Town itself, but in anything involving human activities within the place. That being said, this information is vital in creating a cognitive map that can improve the wayfinding in the Jakarta Old Town.

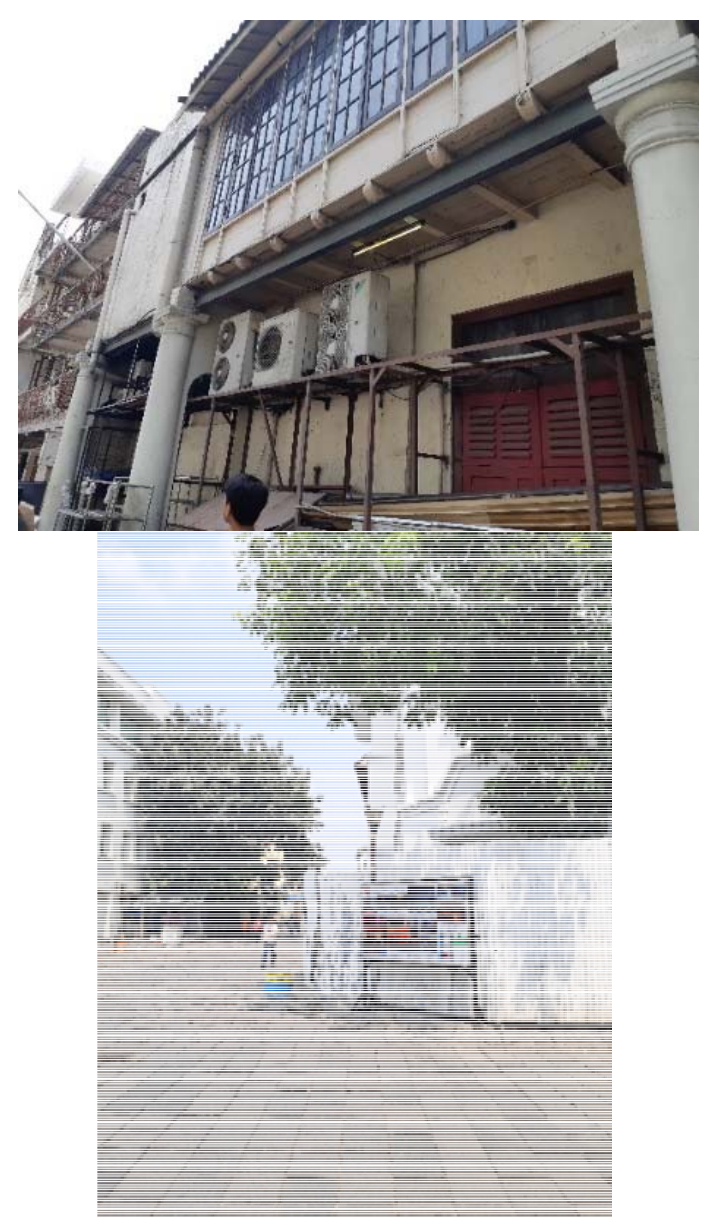

Fig. 4: The obstructed façade of the Old Town.

In addition to the aforementioned findings, it is discovered that the Jakarta Old Town's visitors would exhibit distinctive behaviors when they come across these points of reference. 
Table 2. Observation results of the visitor's feedback behavior.

\begin{tabular}{|c|c|c|}
\hline $\begin{array}{l}\text { Decision } \\
\text { Point }\end{array}$ & Point of Reference & People's Behaviors \\
\hline \multirow{4}{*}{1} & $\begin{array}{l}\text { Groups of people } \\
\text { resting }\end{array}$ & No response \\
\hline & People taking photos & $\begin{array}{l}\text { Slow walking with } \\
\text { occasional stops }\end{array}$ \\
\hline & Photo booth services & $\begin{array}{l}\text { Stopping while } \\
\text { taking photos }\end{array}$ \\
\hline & $\begin{array}{l}\text { People selling/playing } \\
\text { bubble blowers }\end{array}$ & Happy, smiling faces \\
\hline \multirow{3}{*}{2} & Photo booth services & $\begin{array}{l}\text { Stopping while } \\
\text { taking photos }\end{array}$ \\
\hline & $\begin{array}{l}\text { Groups of people } \\
\text { resting }\end{array}$ & No response \\
\hline & Food stalls & Slow walking \\
\hline \multirow[b]{2}{*}{3} & Food stalls & Slow walking \\
\hline & $\begin{array}{l}\text { Groups of people } \\
\text { resting }\end{array}$ & No response \\
\hline \multirow[t]{3}{*}{4} & Live music crowds & $\begin{array}{l}\text { Stopping while } \\
\text { taking photos }\end{array}$ \\
\hline & $\begin{array}{l}\text { People selling/playing } \\
\text { bubble blowers }\end{array}$ & Happy, smiling faces \\
\hline & Photo booth services & $\begin{array}{l}\text { Stopping while } \\
\text { taking photos }\end{array}$ \\
\hline \multirow[t]{2}{*}{5} & $\begin{array}{l}\text { People at the Krukut } \\
\text { River }\end{array}$ & $\begin{array}{l}\text { Stopping while } \\
\text { sightseeing }\end{array}$ \\
\hline & Parking areas & No response \\
\hline \multirow{5}{*}{6} & Photo booth services & $\begin{array}{l}\text { Stopping while } \\
\text { taking photos }\end{array}$ \\
\hline & Bike rentals & $\begin{array}{l}\text { Slow walking with } \\
\text { occasional stops }\end{array}$ \\
\hline & $\begin{array}{l}\text { Groups of people } \\
\text { resting }\end{array}$ & No response \\
\hline & Street vendors & Slow walking \\
\hline & The red car display & $\begin{array}{l}\text { Stopping while } \\
\text { sightseeing }\end{array}$ \\
\hline \multirow{3}{*}{7} & Bike rentals & $\begin{array}{l}\text { Stopping while } \\
\text { taking photos }\end{array}$ \\
\hline & Street vendors & Slow walking \\
\hline & The Fatahillah Museum & Sightseeing \\
\hline
\end{tabular}

As seen from the table, some of the points of reference existing on each decision point encourage positive feedback to the visitors, such as happy faces and inspirations to take photos. These responses are a few examples of hedonic value created from the environment, which further creates a pleasurable experience for the related subjects. According to the framework made by Costello and Edmonds ${ }^{3)}$, all these positive feedbacks may be products of captivation, in which the travelers or visitors are fascinated by the appeal of something, and it makes them feel pleasure. Some of the attractions that captivate the Old Town's visitors are the photo booth services with all the appropriate costumes (famous independence figures, Jakarta's mascot ondel-ondel, the Indonesian folklore character Gatot Kaca, princesses, and so on) as well as their props for the visitors to use while taking photos. In addition, there are street vendors selling a wide variety of food, accessories, and beverages that also have their little spaces for people to sit and rest. The fact that the vendors yell to the crowd to buy their goods further attracts more people, and the presence of live music makes people gather. This huge concentration of people causes those who are just passing by to stop for a while to join the activities - even if to just listen to the music and take photos.

Another factor in pleasurable wayfinding is the sensation created through doing activities, such as cycling through the Fatahillah Plaza and creating the chiming "ding-ding" sound on the bell, taking photos of the sceneries while laughing in the background, taking photos with living statues, and so on. Because these activities happen in the Jakarta Old Town area, the resulting sensation from the activities is considered as the "sensation" that generates a pleasurable feeling.

\section{Conclusion}

The imageability of a place is an essential factor in creating a cognitive map that helps the wayfinding process within it. Based on the results of the observation and analysis on the activities and the reference points in each decision point, one aspect that can improve imageability is the existence of reference points that are easily recognizable by visitors. In this case, the reference points are the ones that involve human activities in them, such as street vendors and photo booth services. These reference points possess some aspects from the pleasure framework made by Costello and Edmonds ${ }^{3)}$, which are captivation and sensation. If implemented, these two aspects can enhance the pleasurable experience of the subjects by giving meaning to the place. Consequently, the wayfinding process is improved, but in a pleasurable and contributive way to the liveliness of the space.

\section{Acknowledgements}

This research is supported by the grant of Hibah PIT 9 2019 from the Directorate of Research and Community Engagement, Universitas Indonesia. We would also like to express our gratitude to all who have contributed to this paper.

\section{References}

1) A. Jacobs, "Great Streets," Cambridge, MA: The MIT Press, 1996.

2) W. Wan Ismail, "User's perception of shopping activities in the historic city of Malacca," Asian Journal of Environment Behaviour Studies, 1(3), 7382 (2010). 
3) T. Sato, "How is a Sustainable Society Established? : A Case Study of Cities in Japan and Germany," Evergreen, 3(2), 25-35 (2016).

4) I. Yaningsih, M. Mahmood, A. Wijayanta, T. Miyazaki, and S. Koyama, "Experimental Study on Dehumidification Technology using Honeycomb Desiccant Block. Evergreen," 5(2), 11-18 (2018).

5) N. Rahman, S. Shamsuddin, and T. Heath, "People's choices and behavior in urban streets," Paper presented at the International Conference on Innovation and Technology for Sustainable Built Environment, UiTM Perak, Malaysia, (2012).

6) M. Read, "Use of color in child care environments: Application of color for wayfinding and space definition in Alabama child care environments," Early Childhood Education Journal, 30(4), 233-239 (2003).

7) O. Suzer, N. Olgunturk, and D. Guvenc, "The effects of correlated color temperature on wayfinding: A study in a virtual airport environment," Displays, 51, 9-19 (2018).

8) T. Chandrasekera, S. Yoon, and N. D'Souza, "Virtual environments with soundscapes: A study on immersion and effects of spatial abilities," Environment and Planning B: Planning and Design, 42(6), 1003-1019 (2015). doi:10.1068/b130087p.

9) M. Hubregtse, "Passenger movement, and air terminal design: artworks, wayfinding, commerce, and kinaesthesia," Interiors, 7:2-3, 155-179 (2016). DOI: $10.1080 / 20419112.2016 .1215678$

10) C. Huang, and S. Yu, "A study of environmental perception patterns of the visually impaired and environmental design," Indoor and Built Environment, 22(5), 743-749 (2013).

11) A. Koutsoklenis, and K. Papadopoulos, "Olfactory cues used for wayfinding in urban environments by individuals with visual impairments," Journal of Visual Impairment \& Blindness, 105(10), 692-702 (2011).

12) A. Afrooz, D. White, and B. Parolin, "Effects of active and passive exploration of the built environment on memory during wayfinding," Applied Geography, 101, 68-74 (2018). doi:10.1016/j.apgeog.2018.10.009

13) L. Grierson, J. Zelek, I. Lam, S. Black, and H. Carnahan, "Application of a Tactile Way-Finding Device to Facilitate Navigation in Persons With Dementia," Assistive Technology, 23(2), 108-115 (2011)

14) J. Peponis, C. Zimring, and Y. Choi, "Finding the Building in Wayfinding. Environment and Behavior," 22(5), 555-590 (1990)

15) J. Tardieum P. susini, H. Kawakami, and S. McAdams, "The design and evaluation of an auditory wayfinding system in a train station," Applied Acoustics, 70(9), 1183-1193 (2009)
16) B. Costello, and E. Edmonds, "A study in play, pleasure and interaction design," Proceedings of the 2007 Conference on Designing Pleasurable Products and Interfaces - DPPI '07, (2007). doi:10.1145/1314161.1314168

17) T. Van Rompay, K. Tanja-Dijkstra, J. Verhoeven, and A. van Es, "On store design and consumer motivation," Environment and Behavior, 44(6), 800820 (2011). doi: 10.1177/0013916511407309

18) H. Nia, R. Atun, and R. Rahbarianyazd, "Perceptionbased method for measuring the aesthetic quality of the urban environment," Open House International, 42(2), 11-19 (2017).

19) P. Symonds, D. Brown, \& V. Lo Iacono, "Exploring an absent presence: Wayfinding as an embodied socio-cultural experience," Sociological Research Online, 22(1), 1-20 (2017).

20) R. Golledge, "Wayfinding Behavior," Baltimore, MD: John Hopkins University Press, 1999.

21) R. Passini, "Wayfinding in Architecture," New York: Van Nostrand Reinhold, 1992.

22) K. Lynch, "The Image of the City," Cambridge, MA: The MIT Press, 1960.

23) D. Appleyard, "The environment as a social symbol: Within a theory of environmental action and perception," Journal of the American Planning Association, 45(2), 143-153 (1979). doi:10.1080/01944367908976952

24) A. Rapoport, Human Aspects of Urban Form. Oxford, England: Pergamon Press, 1977.

25) A. Mehrabian, and J. Russell, "An Approach to Environmental Psychology," Cambridge, MA: The MIT Press, (1974).

26) L. Hopsch, M. Cesario, and R. McCann, "Traveling, inhabiting, and experiencing: A phenomenology for public transit," Environmental and Architectural Phenomenology, 25, 9-14 (2014).

27) D. Berlyne, "Aesthetics and Psychobiology," New York, NY: Appleton-Century-Crofts, (1971). 